\title{
最近の表面・界面の 構造解析技術
}

多様な表面解析技術の中から, 特に光電子分光法について最新 の技術を紹介する. 光電子分光法は非常に有用な状態解析法の 一つであるが，微小部（100 $\mu \mathrm{m}$ 以下）の解析が困難という問 題を有していた。 $30 \mu \mathrm{m}$ 以下さらには $10 \mu \mathrm{m}$ 以下の分解能で イメージ観察とスペクトル解析が可能な技術が生まれ, 副島 啓義 Hiroyoshi Soezima PESM およびXPMS と名付けられた装置が実現しつつある。

（株）島津製作所

表面分析あるいは表面解析はその目的も方法も多く のものが認知され，必需の位置を占めている。しかし この言葉は目的を表わしたものであって方法を具体的 に表わしたものではないので，具体的に記述するとす ればその方法・名称は非常に多様であり，比較的大き な分類でも数 10 種類, 少し細かく記述すれば優に 200 を越えている。そして，より高感度で，より高分 解能で (空間分解能もスペクトル分解能も), より定 量的に, より精度良く解析したい, 他方, より低コス トで，より容易に実施したいという要求の中で，それ ぞれの手法が進歩し新しい手法が生まれている。限ら れた紙面の中でこれらを網羅しようとすれば散漫にな り過ぎるであろうから話題を絞ることにする．解析の 目的・内容を整理すれば，(1)形状観察 (2)成分分析 (3)構造解析である。構造解析の定義については必ずし も明確ではないが，原子配列・原子状態・電子状態は 少なくとも含まれる．表面（特に極表面）・界面・微小 部の構造解析は, 材料の薄層化・多層化・微小化・高 密度化・高機能化が進む中で, その重要性を一段と増 している．にもかかわらず解析能力の方は(1)や(2)に比 べて見劣りするというのが現状である，なぜか．答え は単純で, 難しいからである。極表面や微小部の構造 解析はどうやったらよいかという原理面とその原理を 実現する装置構造がともに難しいからである。しか し，それでもここ数年の間にいろいろな提案があり， 具体的な方法と装置が姿を見せてきた。これらのうち のいくつかは日本で開発が進んでいることも喜ばしい ことである. 本稿ではいくつかの手法の簡単な記述と 特に光電子分光の新しい技術について紹介を行う.

\section{New Technologies of Surface Analysis}

\section{1. 表面・微小部の構造解析のための, ひとつの 共通した考え方}

(1)角度分解：入射電磁波や入射粒子がどの方向から 入射し, どの方向に信号が出るかは, 回折現象・ブロ ック効果・シャドウ効果として原子配列に強く影響を 受ける。したがって角度は有力な情報である。

(2)大きい立体角 : スペクトルの詳細解析, 微量物の 解析には信号強度が重要であることはいうまでもな い.このためには入射強度を大きくするか検出効率を 高める必要がある. 後者のためには検出立体角を大き くするのも有効である。なぜなら通常の装置では発生 信号のごく一部（1\% 以下の場合も珍しくない）しか 検出器に到着していないからである。(1)と(2)は原理・ 構成が逆であるので目的によって使い分けることにな る.

\section{2. いつかの事例}

最近開発されたものあるいは開発が進んでいるもの には例えば，(1)球面鏡アナライザ，(2) CAICISS，(3) 走查 $\mu \mathrm{RHEED}$, (4)光電子分光顕微鏡, などがある. (1)，(2)，(3)はすでにいくつかの報告が出ているので説 明は行わないが，ごく簡単にはつぎのとおりである。

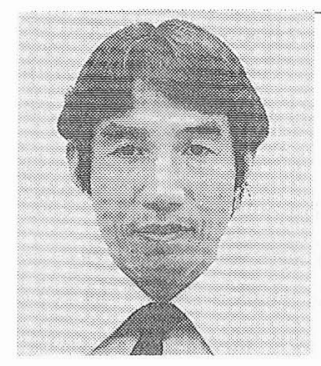

副島啓義 （株）島津製作所 計測本部·部長/KRATOS Group Plc (Barton Dock Road Urmston Manchester, M312. LD England U.K.) 取締役. 1963 年神戸大理学部卒. 1963 年島津製作所入社. 1979 年阪 大工博. 専門は表面分析方法 機器.く趣味〉スケッチ, 音楽 プレイ, 修理, 料理

高分子 41 巻 5 月号 (1992 年) 
図 1 磁界と光電子の動き

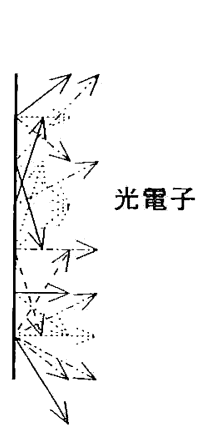

（a）磁界がない場合

(1) Spherical Mirror Analyzer あるいはサリーズ SARIEES, Simultaneous Angle Resolve Ion and Electron Energy Analyzer ともいう, 試料から発生 した荷電粒子の，原理上 180 度すべての，実用的にも 120 度程度の全方位検出を同時に可能にするものであ る。任意のエネルギー粒子のみの発生角度分布がリア ルタイムでスクリーン上に写し出される。また角度分 離をしないで利用すると数百倍も明るいアナライザと して動作する。今後多方面での利用が期待されてい

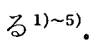

(2)同軸型直衝突イオン散乱分光 : Coaxial Impact Collision Ion Scattering Spectroscopy, カイシスと誌 む. 試料最表面の一層あるいは数層の原子配置の立体 構造を明快に定量的に解明する. 定量的構造解析の最 も進んだ期待される方法の一つである ${ }^{6)}$ 10).

(3)RHEED（高速反射電子回折 ; Reflection HighEnergy Electron Diffraction）はすでに良く知られて いる手法で，また良く利用されている。しかし微小部 の解析は不可能であった. 走査 $\mu$ RHEED は名前のと おり微小部 ( $\mu \mathrm{m}$ 領域) の解析を可能にしたもので, 単に微小部の回折パターンのみならず結晶方位や結晶 回転の分布像も得られる ${ }^{11) ~ 15) . ~ こ れ ら(1)(2)(3) は す 心 ゙ ~}$ て日本で考案・開発されている。

\section{3. 光電子分光顕微鏡}

$\mathrm{X}$ 線光電子分光 (XPS, ESCA) や紫外線光電子分 光 (UPS) が表面の状態解析一特に電子状態一に大恋 重要な役割を果たしていることはいうまでもないが, 微小部の解析は非常に困難であった. $100 \mu \mathrm{m}$ 程度の 領域の分光分析, $10 \mu \mathrm{m}$. 程度の分解能の光電子像観 察はすでに商品レベルで出現しており大きな進歩であ る。しかし本格的なマイクロアナリシスのためには, $10 \mu \mathrm{m}$ オーダさらには $1 \mu \mathrm{m}$ オーダーの分解能を有 し, かつ, 充分な強度とエネルギー分解能の光電子ス ペクトルが得られる装置の出現が待たれる。この実現 のために注目される技術がいくつかある. (1) Beam-
磁力線

\section{（b）強磁界がある場合}

son らによる「超伝導磁場を用いた拡大」, (2) Turner による「Image Band Pass Filter (IBPF)」, (3) Walker による「Snorkel Lens」, (4) Page による $\lceil$ Imaging Spherical Mirror Analyzer (ISMA)」など である。(1)の最初の報告は 1980 年であり，(2)は 1986 年であって新しくはない. しかし当時は実用的装置を 実現する工業技術上の問題などにより，上記目的を達 成するには至らなかった，最近になって(1)と(2)が組み 合わされて画期的装置が生まれつつある. (3)によって すでに $30 \mu \mathrm{m}$ イメージング ESCA が実現した. (3)と (4)が組み合わされて $10 \mu \mathrm{m}$ イメージング ESCA もい ずれ実現するであろう。

\section{3-1. PESM}

Photoelectron Spectro Microscopy ${ }^{16) \sim 21)}$

\section{3-1-1. 強磁界による光電子像の拡大投影}

試料面から発生する光電子はさまざまな角度成分と エネルギー成分をもっているので，光電子に感ずるス クリーンを単に試料面に近づけても試料像は写らな い.この様子を示したのが図1の（a）である.ここ で, 試料を強い磁界の中に置き, 試料面と磁界が注ほ 垂直になるようにする，光電子の運動方向成分には磁 界に対して直角と平行成分があり，直角成分により光 電子は磁力線から離れようとするが, 常に磁界とこの 離れようとする方向の両者に直角な力を受け（フレミ ングの左手の法則), 磁力線の周りの回転運動を始め る. 他方, 磁界に平行成分により光電子は試料面から 離れていく．この様子を示したのが図1の（b）であ る.

図 1 (b) で非常に重要なのは, 試料面から発生 した光電子は横方向（試料の面方向）には浪とんど動 かず，試料の異なった場所から発生した光電子は互い の面方向の位置関係を変えずに試料から離れていくこ とである. そして磁束が段々ひらくにつれ光電子も互 いの位置関係を段々ひらいていく，つまり拡大した磁 束の中にスクリーンを置けば試料面の光電子像が拡大 投影されることになる。 

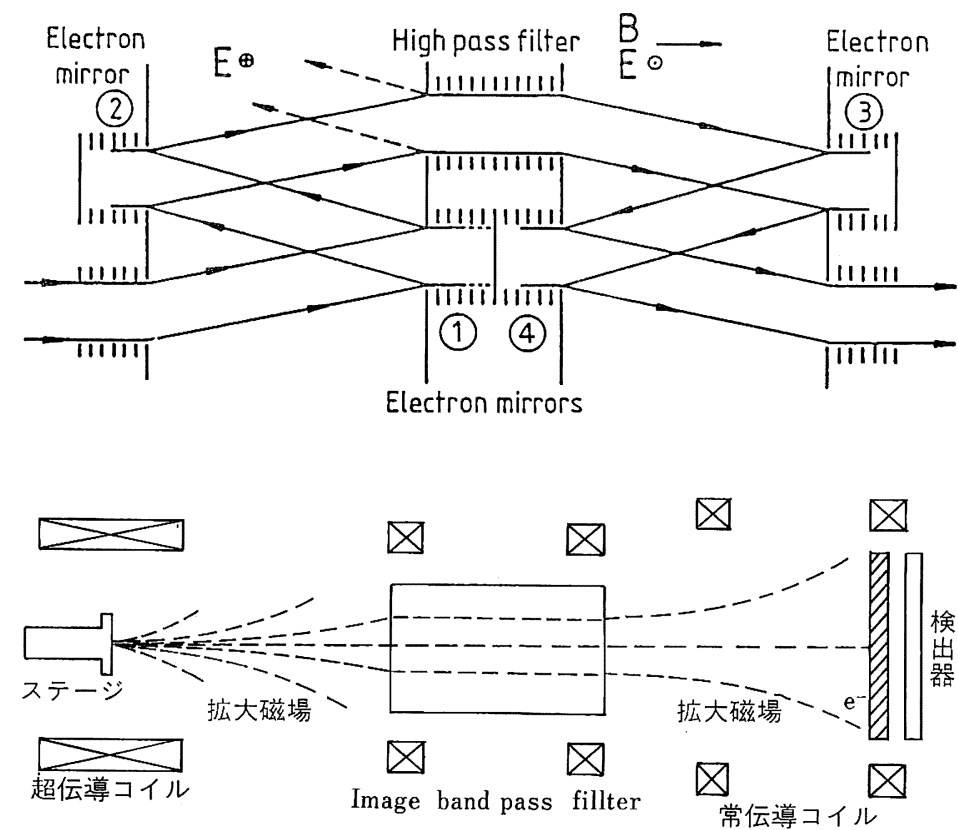

図 2 Image Band Pass Filter の原理
図 3 光電子分光顕微鏡の 構成

\section{3-1-2. IBPF}

図 2 に示すのが原理図である. Electron Mirror と 書かれているのがあるエネルギー以下の電子のみを反 射して次段へおくるつまり Low-pass である。これ らの複数の Low-pass と High-pass filter により任意 のエネルギーバンドの電子が取り出される。さらにこ れらの filter 群が電場磁場の中に置かれることによ り，軌道偏向形のアナライザーとしても作用する．例 えば，入りロから入って来た電子が L1 に向かうと き，あるエネルギーより高すぎても低すぎても L1 に は到達しない，このようにして非常にエネルギー分解 能の高いアナライザーとして機能する。

\section{3-1-3. 装置構成}

図 1 (b) の強磁場と図 2 のエネルギーアナライザを 組み合わせると, 光電子分光顕微鏡が実現する. 図 3 に主要な構成要素の配置を示す．ただし光源（X 線や 紫外線）は示していない. 試料から発生した光電子は 超伝導コイルが作る強磁場によって，その相対位置を 拡大しながら IBPF に到達する. IBPF は周りには別 のコイルが配置されておりこのコイルによって IBPF の中に均一な平行磁場を作っている. IBPF によって 特定のエネルギーのみがセレクトされてスクリーン （検出器）に向かう. IBPF とスクリーンの間にはさ らに別のコイルが作る拡大磁場があり, 拡大光電子像 がスクリーンに投影される.

この PESM は原理上, 光電子エネルギーが小さい ほど, 磁場が強いほど位置分解能が良くなる，装置が
理想的に作られたとすると計算上は次の性能となる。 エネルギー分解能はおよそ $E / \Delta E \fallingdotseq 1000$ である。

磁場の強さを 7 Tesla, 信号検出の立体角を 20 度 とすると, 光電子のエネルギー $3 \mathrm{eV}, 30 \mathrm{eV}, 300 \mathrm{eV}$ に対して, 位置分解能はそれぞれ $0.3 \mu \mathrm{m}, 1 \mu \mathrm{m}, 3$ $\mu \mathrm{m}$ になる。 また，比較的エネルギーの高い $1000 \mathrm{eV}$ の電子を大きな立体角 60 度で検出すると $15 \mu \mathrm{m}$ に, 小さいエネルギー $0.3 \mathrm{eV}$ の電子を 6 度で検出すると $30 \mathrm{~nm}$ になる.

\section{3-2. XPMS}

\section{(Xray Photoelectron Micro-Spectroscopy)}

\section{3-2-1. Snorkel レンズと電気的走査 ${ }^{22)}$}

試料の下方に Snorkel レンズと名付けられた磁場 レンズを設置する。このレンズにより試料から発生し た光電子は試料上方のスクリーンに拡大実像を結ぶ. このスクリーンの一部に穴を開けておけば，試料の特 定部分の信号のみがエネルギーアナライザと検出器へ 向い微小部分析が実現する。従来から試料上方に静電 レンズを設けて同様のことが行われてきたが， $70 \mu \mathrm{m}$ 程度が実用的限界であった．主な理由は信号強度が極 端に小さくなってしまうからである. Snorkel レンズ がこの問題を解決し $30 \mu \mathrm{m}$ 以下の微小部に対して実 用分析が可能になった. $30 \mu \mathrm{m}$ での強度を従来と比 べることは無理であるが（従来は不可能なため值が無 い) $70 \mu \mathrm{m}$ では 20〜30 倍である.さらに電気的走査 による光電子像も得られるようになった。レンズとエ ネルギーアナライザの間に走査電極を設け，これによ 

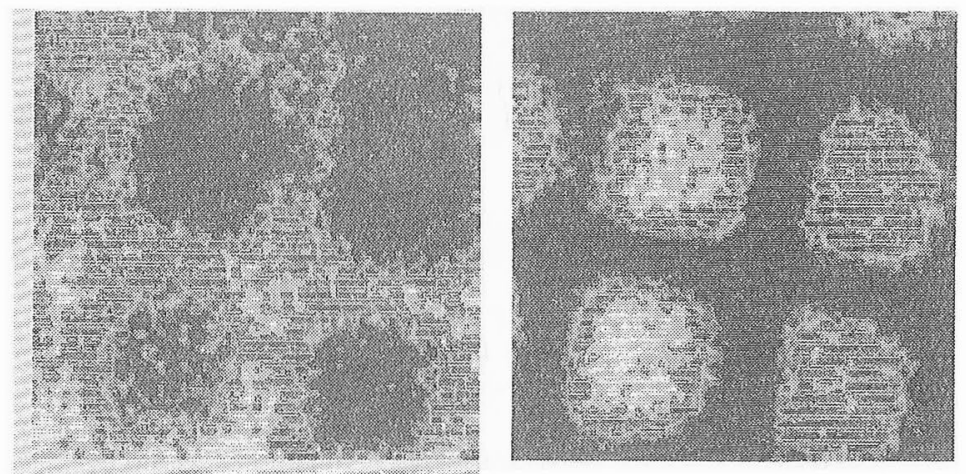

200 uin

(a) メッシュマスクにより $\mathrm{CF}_{2}$ 結合のまま

(b) イオン照射によりグラファイト化している

(データはクレイトス社 Street 氏の好意による)

図 4 Ar イオン照射したPVDF のカーボン光電子像
文

献

1) H. Daimon: Rev. Sci. Instrum., 59, 545 (1988)

2）大門 寛, 井野正三:真空, 31, 954 (1988)

3) H. Daimon, S. Ino: R.S.I., 61, 57 (1990)

4) H. Daimon, S. Ino: Proc. IVC11/ICSS-7 in Cologne (1989)

5）大門 寛, 加藤 勲, 銭谷福男, 副 島啓義 : 島津評論, 47, 5 (1990)

6) M. Katayama, E. Nomura, N. Kanekama, H. Soejima, M. Aono: Nucl. Instrum. Methods Phys. Res., B33, 857 (1988)

7）青野正和:応用物理， 55,377 (1986)

8）青野正和, 片山光浩: 応用物理, 57, 1686 (1988)

り光電子を 2 次元走査することにより，走查に同期し て試料上の微小点からの信号が順次検出され二次元走 查像が得られる。操作感覚は EPMA の X 線像と同様 である。なお，これらの技術を折り込んだ装置はすで に商品として発売された。

図 4 は, PVDF (Poly Vinyl Difluoride) 表面をメ ッシュでマスクし, $4 \mathrm{keV} \mathrm{Ar}$ イオンを照射した後の 光電子像である. $\mathrm{CF}_{2}$ 結合していたカーボンが照射 によりグラファイト化している.

\section{3-2-2. イメージング球面鏡アナライザ：ISMA ${ }^{23)}$}

試料表面の拡大光電子像を静的に得る試みはいろい ろ行われており（3-1項もそうであるが），その多く は静電レンズによる結像形である。しかし，イメージ 化することと高エネルギー分解能でスペクトル解析す ることは矛盾することがいくつかあり, 信号強度が弱 くスペクトル解析能力がそしかった. 同芯 3 球面のア ナライザ ISMA がこの問題を大幅に改善した。 大・ 中・小 3 半球から成るこのアナライザは中半球がグリ ッドになっており，信号は小半球と中半球の間から入 る.イメージの場合の信号はグリッドを通り抜けて, 中半球と大半球により中エネルギー分解能で得られ, 高エネルギー分解能をスペクトルは小半球と中半球に より, 通常の静電半球アナライザと同様に得られる. この ISMA と Snorkel レンズを組み合わせることに よりリアルタイムのイメージングと高感度スペクトル 解析が同一視野に対して実現することとなった。

簡単過ぎる記述になってしまったが，高分子材料の 解析により特に有用な XPS (ESCA) を中心に，本格 的なマイクロアナライザとして機能する最新の技術を 紹介した．今後画期的アプリケーションが進むことを 願ってやまない.
9) 青野正和, 片山光浩 : 表面科学, 10,676 (1989)

10) 林 茂樹, 丸井隆雄, 寺本 晃, 谷口純一, 梶川鉄夫, 副 島啓義, 野村英一, 片山光浩, 青野正和: 島津評論 : 47 , 11 (1990)

11）坪内和夫, 益一哉, 田中正則, 大見忠弘, 御子柴宣夫, 林 茂樹, 丸井隆雄, 寺本 晃, 暒川鉄夫, 副島啓義: 島 津科学計測ジャーナル, 1, 2, 50 (1989)

12) K. Tsubouchi, K. Masu, M. Tanaka, Y. Hiura, T. Ohmi, N. Mikoshiba, S. Hayashi, T. Marui, A. Teramoto, T. Kajikawa, H. Soejima : Extended Abstracts 21st Conf. Solid State Devices and Materials, 217 (1989)

13) K. Tsubouchi, K. Masu, M. Tanaka, Y. Hiura, T. Ohmi, N. Mikoshiba, S. Hayashi, T. Marui, A. Teramoto, T. Kajikawa, H. Soejima:Japan. Jour. Appl. Phys., 28, L2075 (1989)

14）丸井隆雄, 林 茂樹, 寺本 晃, 梶川鉄夫, 副島啓義, 坪 内和夫, 益一哉, 田中正則, 樋浦洋平, 大見忠弘, 御子 柴宣夫: 日本学術振興会マイクロビームアナリシス第 141 委員会第 62 回研究会資料, No.703 (1989)

15）坪内和夫, 益 一哉, 田中正則, 樋浦洋平, 大見忠弘, 御 子柴宣夫, 丸井隆雄, 林 茂樹, 寺本 晃, 梶川鉄夫, 副 島啓義: 島津評論, 47, 23 (1990)

16) G. Beamson, H.Q. Porter, D.W. Turner:J. Phys., E13, 64 (1980)

17) G. Beamnon, H.Q. Porter, D.W. Turner : Nature, 290, 556 (1981)

18) D.W. Turner, I.R. Plummer, H.Q. Porter : Ann. N. Y. Acad. Sci., 483, 354 (1986)

19) D.W. Turner, I.R. Plummer, H.Q. Porter: Rev. Sci. Instrum., 1988, 59, 45

20) D.W. Turner: Chemistry in Britain Aug., 797 (1987)

21）副島啓義 : 応物スクールテキスト 1991 春期

22) A.R. Walker : UK 特許 GB8609740, USA および日本 申請中

23） S.C. Page : UK 特許 GB2244369A, USA および日本申 請中 